\title{
UJI AKTIVITAS ANTIBAKTERI PADA GEL EKSTRAK KULIT BUAH NAGA MERAH (Hylocereus lemairei (Hook). Britton \& Rose) TERHADAP Propionibacterium acnes
}

\author{
Ira Oktaviani Rz ${ }^{1}$, Agung Hidayat ${ }^{2}$ \\ ${ }^{1}$ Poltekkes Kemenkes Riau \\ ${ }^{2}$ D III Analis farmasi dan makanan, FKIK Universitas Abdurrab \\ ira@pkr.ac.id
}

\begin{abstract}
Dragon fruit is a type of cactus from the genera Hylocereus and Selenicereus, in the utilization of dragon fruit, especially ordinary red dragon fruit is only fixed on the fruit flesh, while the skin is not yet common to eat and become waste. Though red dragon fruit skin has many benefits, one of which is antibacterial. This study aims to determine the diameter of the antibacterial inhibitory zone of red dragon fruit skin gel with concentrations of 30\%, 50\%, and 70\% against Propionibacterium acnes. This research was carried out by the method of wells in MHA media using positive controls and negative controls. From the results of the research conducted it can be concluded that the dragon fruit peel extract gel (Hylocereus lemairei (Hook). Britton \& Rose) is able to inhibit the growth of Propionibacterium acnes with an average inhibitory power at concentrations of $30 \%, 50 \%$, and $70 \%$, is $8,66 \mathrm{~mm}, 12.06 \mathrm{~mm}$, and $15 \mathrm{~mm}$ and the positive control obtained an average of $25 \mathrm{~mm}$.
\end{abstract}

Keyword : Antibacterial activity, clindamycin, inhibition zone, red dragon fruit skin (hylocereus lemarei (hook). britton \& rose ), Propionibacterium acnes

Abstrak Buah naga merupakan jenis kaktus dari marga Hylocereus dan Selenicereus, dalam pemanfaatan buah naga terutama buah naga merah biasa hanya terpaku pada daging buahnya, sedangkan kulitnya belum lazim untuk dimakan dan menjadi limbah. Padahal kulit buah naga merah memiliki banyak manfaat salah satunya adalah sebagai antibakteri. Penelitian ini bertujuan untuk mengetahui berapa diameter zona hambat antibakteri gel kulit buah naga merah dengan kosentrasi 30\%, 50\%, dan $70 \%$ terhadap Propionibacterium acnes. Penelitian ini dilakukan dengan metode sumuran pada media MHA menggunakan kontrol positif adalah klindamisin dan kontrol negatif adalah basis gel. Dari hasil penelitian yang dilakukan dapat disimpulkan bahwa gel ekstrak kulit buah naga (Hylocereus lemairei (Hook). Britton \& Rose) mampu menghambat pertumbuhan Propionibacterium acnes dengan diameter daya hambat rata-rata pada konsentrasi 30\%, 50\%, dan 70\%, adalah 8,66 mm, 12,06 $\mathrm{mm}$, dan $15 \mathrm{~mm}$ serta pada kontrol positif didapat rata-rata $25 \mathrm{~mm}$.

Kata kunci : Aktivitas antibakteri, klindamisin, zona hambat, kulit buah naga merah ( hylocereus lemarei (hook). britton \& rose ), Propionibacterium acnes

\section{Pendahuluan}

Buah naga merupakan jenis kaktus dari marga Hylocereus dan Selenicereus [1]. Buah naga memiliki empat jenis spesies, yaitu buah naga putih (Hylocereus undatus), buah naga daging merah atau buah naga merah (Hylocereus polyrhizus), buah naga daging super merah (Hylocereuscostaricensis), dan buah naga kulit kuning daging putih (Selenicerius megalanthus) [2]. Dalam pemanfaatan buah naga terutama buah naga merah biasa hanya terpaku pada daging buahnya, sedangkan kulitnya belum lazim untuk dimakan dan menjadi limbah. Padahal kulit buah naga merah memiliki banyak manfaat salah satunya adalah sebagai antibakteri [3].

Skrining fitokimia yang dilakukan oleh Amalia dan Wahdaningsih menunjukan bahwa, ekstrak fraksi nheksan kulit buah naga merah mengandung senyawa alkaloid dan triterpenoid yang memiliki aktivitas antibakteri [4][3]. Dan hasil penelitian Manihuruk menunjukkan ekstrak menggunakan pelarut air, kulit buah naga merah terbukti memiliki aktivitas antibakteri yang berasal dari senyawa metabolit sekunder flavonoid, saponin, triterpenoid, dan steroid [5]. Penelitian Nurmahani membuktikan bahwa ekstrak n-heksan, kloroform dan etanol kulit buah naga merah memiliki aktivitas antibakteri pada bakteri Gram positif dan Gram negatif [6]. 
JOPS (Journal Of Pharmacy and Sciences)

Vol 3 No 1 Desember 2019

Propionbacterium acnes merupakan bakteri Gram positif yang dapat menyebabkan infeksi pada kulit [7]. Salah satu bentuk infeksi kulit ialah jerawat (akne). Jerawat (akne) merupakan penyakit kulit yang muncul pada saat kelenjer minyak pada kulit terlalu aktif dan terinfeksi bakteri [8]. Pengobatan jerawat dapat menggunakan sediaan gel yang biasanya mengandung antibiotik didalamnya.

Gel merupakan sediaan semipadat terdiri dari suspensi yang dibuat dari partikel anorganik yang kecil atau molekul organik yang besar, terpenetrasi oleh suatu cairan [9]. Karena sediaan gel memiliki keuntungan banyak mengandung air, mudah diserap kulit, dan suatu tipe yang dapat dicuci dengan air [10]. Melihat dari uraian diatas maka perlu dilakukan penelitian terhadap gel dari kulit buah naga sebagai antibakteri pada Propionbacterium acnes, yang mana bakteri tersebut menjadi salah satu masalah penyebab jerawat.

\section{Metode Penelitian}

\subsection{Desain Penelitian}

Penelitian ini merupakan penelitian deskriptif untuk melihat aktivitas antibakteri gel ekstrak kulit buah naga yang dilakukan dengan dengan metode sumuran. Metode ini terdiri dari 5 sumur, diantaranya 3 sumur untuk sampel, 1 sumur untuk basis gel (kontrol negatif), dan 1sumur untuk gel klindamisin (kontrol positif).

\subsection{Sampel}

Sampel yang digunakan dalam penelitian ini adalah kulit buah naga merah (Hylocereus lemairei (Hook.) Britton dan Rose) yang dibeli di toko buah Pekanbaru, lalu diformulasikan menjadi bentuk sediaan gel.

\subsection{Tempat dan Waktu Penelitian}

Penelitian dilakukan di Laboratorium Anafarma I Universitas Abdurrab dan Laboratorium Mikrobiologi SMAK Abdurrab Januari 2018.

\subsection{Alat dan Bahan}

Alat yang digunakan adalah beakerglass, erlemeyer, gelas ukur, cawan petri, pipet tetes, pipet ukur, kawat ose, timbangan analitik, bunsen, asbes, spatula, korek api, autoklaf, hot plate, Inkubator anaerob, kapas lidi steril, penggaris, spuit, serbet, kertas padi, batang pengaduk, tabung reaksi, rak tabung reaksi, mikropipet, pinset, lumpang, alu, gelas ukur, botol vial, pisau.

Bahan yang digunakan adalah kulit buah naga, asam sitrat, cera alba, vaselin albi, prophilen glikol, alkohol 70\%, akuades, MHA (Mueller Hinton Agar), $\mathrm{NaCl}$ fisiologis ( $\mathrm{NaCl}$ 0,9\%), $\mathrm{H} 2 \mathrm{SO} 4, \mathrm{BaCl} 2$, Strain Propionibacterium acnes, tissue, alumunium foil, krim klindamisin, masker, handscoon.

\subsection{Prosedur Kerja}

1. Pembuatan Ekstrak Kulit Buah Naga Merah

Sampel yang akan dibuat ialah buah naga merah yang dibeli di toko buah di kota Pekanbaru. Buah naga merah dibelah, kemudian diambil kulitnya dibersihkan terlebih dahulu, kemudian ditiriskan dan kulit buah naga tersebut dipotong- potong $\pm 2 \mathrm{~mm}$. Timbang kulit buah naga sebanyak 50 gram. Pembuatan ekstrak kulit buah naga merah dilakukan dengan metode maserasi didalam beaker glass menggunakan akuades dengan penambahan asam sitrat (1:1), sebanyak $50 \mathrm{ml}$ campuran aquades dan asam sitrat dimasukkan kedalam beaker glass ditutup dengan alumunium foil selama \pm 15 menit, kemudian filtrat disaring.

2. Pembuatan Basis Gel 
JOPS (Journal Of Pharmacy and Sciences)

Vol 3 No 1 Desember 2019

Semua bahan ditimbang. Na-CMC (0,9 g) didispersikan dengan propilenglikol (3 g) di dalam lumpang, mula-mula campuran diaduk kuat untuk mencegah pengendapan kemudian ditambahkan dapar fosfat $\mathrm{pH} 7$ (8,03 g), diaduk perlahan, ditambahkan air $(8,07 \mathrm{ml})$, diaduk perlahan untuk mencegah terbentuknya gelembung udara sampai sediaan cukup kental dan tidak susah untuk dituang.

3. Pembuatan Gel Ekstrak Kulit Buah Naga Merah

Pembuatan gel ekstrak kulit buah naga merah 30\% sebanyak 7 gram basis gel dimasukkan kedalam lumpang, kemudian ditambahkan 3 gram ekstrak kulit buah naga merah. Gerus hingga homogen. Sehingga didapat berat gel sebanyak 10 gram. Pembuatan gel ekstrak kulit buah naga merah 50\%. sebanyak 5 gram basis gel dimasukkan kedalam lumpang, kemudian ditambahkan 5 gram ekstrak kulit buah naga merah. Gerus hingga homogen. Sehingga didapat berat gel sebanyak 10 gram. Pembuatan gel ekstrak kulit buah naga merah $70 \%$ sebanyak 3 gram basis gel dimasukkan kedalam lumpang, kemudian ditambahkan 7 gram ekstrak kulit buah naga merah. Gerus hingga homogen. Sehingga didapat berat gel sebanyak 10 gram.

4. Pembuatan media Mueller Hinton Agar (MHA)

Media Mueller Hinton Agar (MHA) ditimbang sebanyak 3,8 gram. Masukkan kedalam Erlenmeyer, dilarutkan dalam $100 \mathrm{ml}$ akuades kemudian dipanaskan sampai mendidih sambil diaduk hingga terlarut secara sempurna. Erlenmeyer ditutup dengan kapas, kemudian disterilkan didalam autoklaf suhu $121^{l} \mathrm{C}$. Tekanan 2 atm selama 15 menit kemudian tuangkan kedalam tiga buah cawan petri steril yang telah ditambahkan darah.

5. Pembuatan media inokulum bakteri uji

Suspensi bakteri diambil dengan kapas lidi steril, kemudian dioleskan pada permukaan media hingga semua permukaan media teroleskan suspensi secara merata.

6. Pembuatan sumur tempat pengujian bakteri

Media MHA yang telah mengering di lubang menggunakan ujung pipet tetes yang tersebih dahulu di sterilisasi menggunakan alkohol. Media tersebut di buat sumur sebanyak 5 sumur, 3 sumur untuk sampel, 1 sumur untuk basis gel (kontrol negatif), dan 1sumur untuk gel klindamisin (kontrol positif).

7. Uji Aktivitas Antibakteri

Uji aktivitas antibakteri gel ekstrak kulit buah naga Sumuran yang sudah dibuat pada media pengujian dimasukkan sampel, kontrol negatif, dan kontrol positif menggunakan spuit, kemudian diinkubasi dalam inkubator anaerob pada suhu $35 \pm 2{ }^{\circ} \mathrm{C}$ selama 24 jam, setelah itu diukur diameter daerah aktivitas antibakteri (zona jernih) disekitar pecandang menggunakan mistar berskala dengan cara mengukur secara horizontal dan vertikal kemudian hasil yang didapat dikurangi diameter sumuran $7 \mathrm{~mm}$ [13].

8. Analisa Data

Aktivitas antibakteri ditentukan dengan mengukur zona bening disekitar sumur menggunakan jangka sorong. Data disajikan dalam bentuk tabel dan diolah secara deskriptif 
JOPS (Journal Of Pharmacy and Sciences)

Vol 3 No 1 Desember 2019

\section{Hasil dan Pembahasan}

Tabel 1. Hasil Uji Aktivitas Gel Ekstrak Kulit Buah Naga

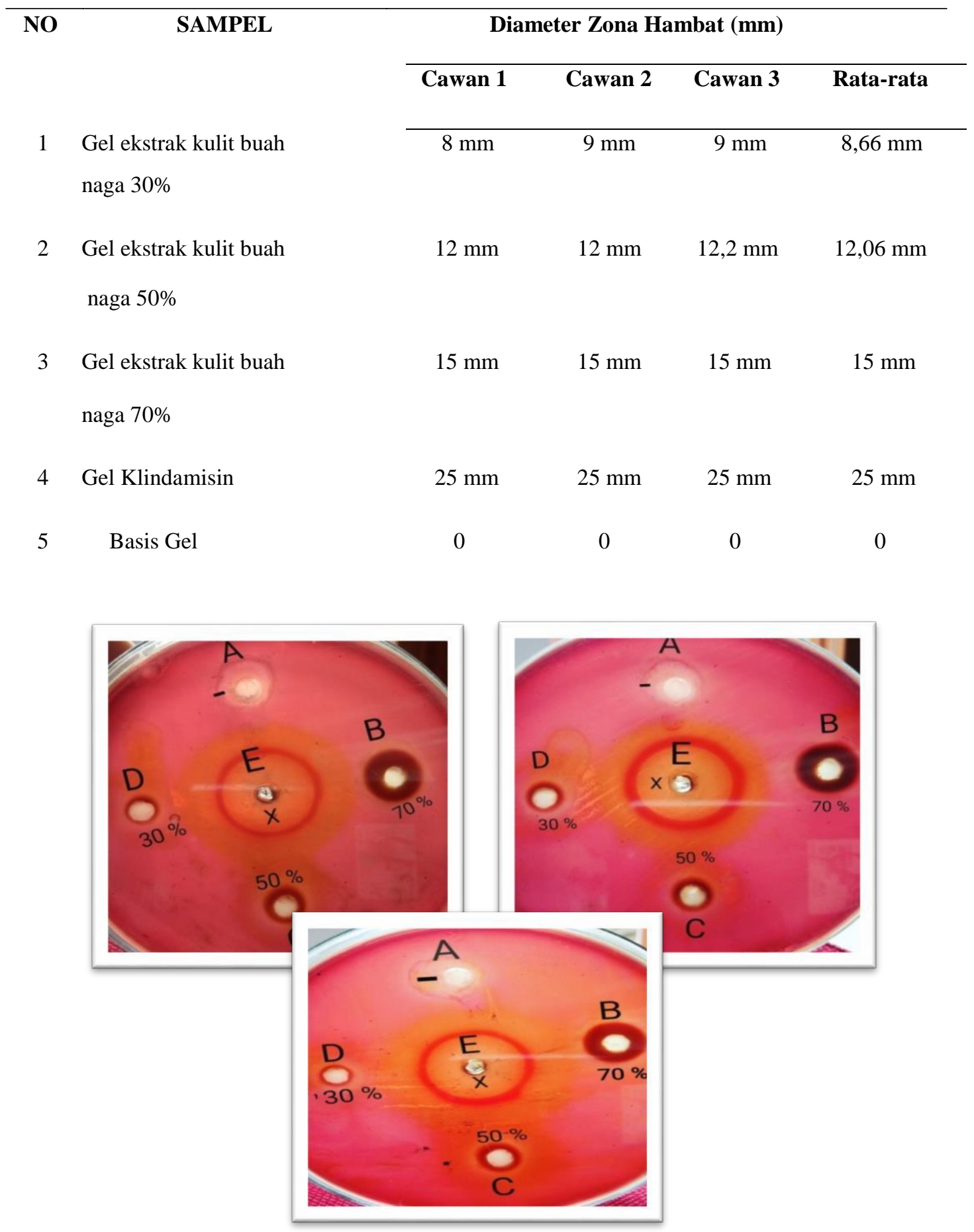

Gambar 1. Uji Aktivitas Gel Ekstrak Kulit Buah Naga 
JOPS (Journal Of Pharmacy and Sciences)

Vol 3 No 1 Desember 2019

\section{Pembahasan}

Penelitian ini bertujuan untuk mengetahui aktivitas antibakteri gel ekstrak kulit buah naga Merah (Hylocereus lemairei (Hook). Britton \& Rose) dalam menghambat pertumbuhan Propionibacterium acnes. Pada pengujian aktivitas antibakteri, diawali dengan pembuatan ekstrak yang dilakukan dengan cara mencuci kulit buah naga merah lalu dirajang tipis untuk memperluas permukaan sampel sehingga mempermudah pelarut masuk kedalam membran sel sampel dan mempercepat zat aktif keluar dari dalam sel. Tahap selanjutnya adalah proses ekstraksi 50 gram kulit buah naga merah dengan metode maserasi menggunakan campuran akuades dan asam sitrat (1:1) sebanyak $50 \mathrm{ml}$. Akuades digunakan sebagai pelarut karena senyawa flavonoid yang berperan sebagai antibakteri bersifat polar, sehingga harus menggunakan pelarut yang sifatnya juga polar agar senyawa tersebut dapat keluar dari sel dan tidak rusak selama proses ekstraksi. Sedangkan penambahan asam sitrat berfungsi mendenaturasi membran sel tanaman, yang kemudian melarutkan pigmen antosianin sehingga dapat keluar dari sel. Kulit buah naga merah mengandung pigmen antosianin yang memberikan warna merah. Antosianin bersifat tidak stabil apabila dipanaskan, namun akan lebih stabil dalam suasana asam [15].

Pada penelitian ini dilakukan proses ekstraksi sebanyak tiga kali perlakuan, tujuannya untuk mendapatkan senyawa antosianin yang sesuai pada panjang gelombang maksimumnya. Pada penelitian ini, perlakuan pertama kali dilakukan ekstraksi terhadap simplisia dengan proses pemanasan menggunakan rotary evaporator suhu $100{ }^{\circ} \mathrm{C}$ dan didapatkan maserat berwarna coklat, kemudian dilakukan scanning terhadap panjang gelombang maksimum antosianin menggunakan spektrofotometri UV-VIS, didapatkan nilai absorbansi sebesar 1,807 pada panjang gelombang $254 \mathrm{~nm}$. Kemudian dilakukan perlakuan untuk kedua kalinya ekstraksi terhadap kulit buah naga segar dengan proses pemanasan menggunakan magnetic stirer didapatkan maserat berwarna coklat kemerahan, kemudian dilakukan lagi scanning terhadap panjang gelombang maksimum antosianin, didapatkan nilai absorbansi sebesar 3,391 pada panjang gelombang $255 \mathrm{~nm}$, dan perlakuan yang terakhir dilakukan terhadap kulit buah naga segar yang diekstraksi langsung menggunakan metode maserasi tanpa dilakukan proses pemanasan didapatkan ekstrak berwarna merah, dengan nilai absorbansi sebesar 0,476 pada panjang gelombang $533 \mathrm{~nm}$.

Tabel 2. Panjang gelombang maksimum penentuan antosianin

\begin{tabular}{ccc}
\hline Proses ekstraksi & Panjang gelombang (nm) & Absorbansi \\
\hline I & 254 & 1,807 \\
II & 255 & 3,391 \\
III & 533 & 0,476 \\
\hline
\end{tabular}

Berdasarkan data diatas tersebut, panjang gelombang maksimum dari antosianin yang digunakan yaitu pada perlakuan pengukuran ekstrak kulit buah naga merah yang ketiga. Karena menurut ciri spektrumnya, antosianin memiliki panjang gelombang maksimum berkisar antara 475 - $560 \mathrm{~nm}$ [16]. Ekstrak kulit buah naga merah yang diperoleh sesuai dengan penelitian Manihuruk mendapatkan ekstrak kulit buah naga merah berwarna merah menggunakan pelarut akuades dengan penambahan asam sitrat. Oleh karena itu peneliti menggunakan ekstrak hasil 
JOPS (Journal Of Pharmacy and Sciences)

Vol 3 No 1 Desember 2019

maserasi tanpa pemanasan karena selain warna yang diperoleh bagus untuk sediaan gel, antosianinnya juga terdapat di dalam ekstrak tersebut, dilihat dari panjang gelombang yang di dapat yakni $553 \mathrm{~nm}$ yang sesuai dengan literatur. Kemudian dilanjutkan dengan pembuatan formulasi gel. Pertama dilakukan pembuatan basis gel yang terdiri dari Na-CMC (0,9 g), propilenglikol (3 g), dapar fosfat pH 7 (8,03 g) dan air (8,07 g). Na-CMC berfungsi sebagai gelling agent yang merupakan bahan pembentuk gel. Propilenglikol berfungsi sebagai humektan yang akan menjaga kestabilan sediaan dengan cara mengabsorbsi lembab dari lingkungan dan mengurangi penguapan air dari sediaan. Selain menjaga kestabilan sediaan, secara tidak langsung humektan juga dapat mempertahankan kelembaban kulit sehingga kulit tidak kering. Dapar fosfat $\mathrm{pH} 7$ berfungsi untuk menjaga $\mathrm{pH}$ dan stabilitas sediaan. Pada penelitian ini, dapar fospat tidak diuji ph nya, sehingga sediaan gel tidak diketahui nilai $\mathrm{pH}$ nya. Air berfungsi sebagai pelarut dalam formulasi gel [9]. Lalu dilanjutkan dengan pembuatan gel ekstrak kulit buah naga merah dengan tiga variasi konsentrasi yaitu 30\%, 50\% dan 70\%. Gel yang didapatkan bewarna merah muda, dengan visikositas gel tidak kaku dan tidak cair, ketika di tuangkan tidak mengalir seperti air.

Dalam pengujian aktivitas antibakteri, Sebelum dilakukan pengujian, alat-alat kaca disterilkan terlebih dahulu didalam oven pada suhu $160-170^{\circ} \mathrm{C}$ selama $2-3$ jam tujuannya untuk mematikan dan membebaskan organisme yang terdapat pada alat- alat kaca tersebut. Sebelum dimasukkan kedalam oven, alat-alat kaca dibungkus dengan kertas padi untuk mencegah terjadinya kontaminasi pada waktu pendinginan atau penyimpanan [9].

Sebagai kontrol positif digunakan antibiotik gel klindamisin. Klindamisin merupakan antibiotik yang memiliki indikasi dapat mengobati jerawat. Antibiotik gel Klindamisin sebesar 0,5-5 mg/ml dapat menghambat streptococcus, staphylococcus, dan pneumococcus [17]. Kontrol negatif yang digunakan adalah basis gel.

Pengujian aktivitas antibakteri ekstrak gel kulit buah naga merah (Hylocereus leimaire (Hook). Britton \& Rose) pada penelitian ini menggunakan 3 cawan petri dengan perlakuan yang sama yaitu dengan variasi konsentrasi gel 30\%, 50\%, dan 70\%. Hasil penelitian pada ketiga cawan petri ini didapatkan diameter zona hambat rata-rata pada konsentrasi 30\% sebesar 8,66 mm dikategorikan sensitif sedang, 50\% sebesar 12,06 mm dengan kategori sensitif sedang, dan 70\% sebesar $15 \mathrm{~mm}$ dikategorikan sensitif sedang. Diameter zona hambat pada klindamycin (kontrol positif) adalah $25 \mathrm{~mm}$, sedangkan basis gel sebagai kontrol negatif tidak membentuk daya hambat.

Dari hasil penelitian yang telah dilakukan, maka kulit buah naga merah (Hylocereus lemairei (Hook). Britton \& Rose) terbukti memiliki zat aktif yang bersifat antibakteri, ditunjukkan dengan adanya zona hambat yang memiliki rata-rata diameter daerah hambatan dengan aktivitas sedang 8-15 mm. Menurut Yadav dan Bishe aktivitas antibakteri dikatakan lemah jika memiliki daerah hambatan antara $\leq 5 \mathrm{~mm}$, aktivitas sedang memiliki daerah hambatan antara 5-10 mm, aktivitas kuat memiliki daerah hambatan kuat antara 10-20 mm, serta aktivitas sangat kuat dengan diameter daerah hambatan $\geq 20 \mathrm{~mm}$.

\section{Kesimpulan}

Dari hasil penelitian yang dilakukan dapat disimpulkan bahwa gel ekstrak kulit buah naga (Hylocereus lemairei (Hook). Britton \& Rose) mampu menghambat pertumbuhan Propionibacterium acnes dengan diameter daya hambat rata-rata pada konsentrasi $30 \%, 50 \%$, dan $70 \%$, adalah 8,66 mm, 12,06 mm, dan $15 \mathrm{~mm}$ serta pada kontrol positif didapat rata-rata $25 \mathrm{~mm}$. 
JOPS (Journal Of Pharmacy and Sciences)

Vol 3 No 1 Desember 2019

\section{REFERENSI}

Amalia, S. 2014. Uji Aktivitas Antibakteri Fraksi n-Heksan Kulit Buah Naga Merah (Hylocereus polyrhizus Britton \& Rose) Terhadap Bakteri Staphylocuccus aureus ATCC 25923.Jurnal Fitofarmaka. Volume 1(2): 61-64

Agoes, A. 2010. Tanaman Obat Indonesia. Pekanbaru : Salemba Medika

Bai, A. R. 2011. Buku Pintar Asal Usul Flora \& Fauna. Jogjakarta : Diva Press

Corwin, E. J. 2001. Buku Saku Patofisiologi. Jakarta: Kedokteran EGC

Departemen Kesehatan Republik Indonesia. 1995. Farmakope Indonesia, Edisi IV. Jakarta

Farida, R, dan F. C, Nisa. 2015. Ekstraksi Antosianin Limbah Kulit Manggis Metode Microwave Assisted Extraction (Lama Ekstraksi dan Rasio Bahan:Pelarut). Journal Pangan dan Agroindustri, vol 3(2).

Harmita dan Radji, M. 2008. Buku Analisis Hayati Edisi 3. Jakarta: Buku Kedokteran

Jawetz, Menick, dan Aldebarg’s. 2005. Mikrobiologi Kedokteran Edisi 23. Jakarta: Salemba medika

Kumesan,Y. A. N., P. V. Y. Yamlean, dan H. S. Supriati. 2013. Formulasi Dan Uji Aktivitas Gel Antijerawat Ekstrakumbi Bakung (Crinum asiaticum L.) Terhadap Bakteristaphylococcus aureus Secara In Vitro. Jurnal Farmasi. Volume 2 (2): 18-26

Katzung, B.G. 2004. Farmakologi Dasar dan Klinis Edisi 8. Jakarta: Salemba Medika

Manihuruk, F.M., T. Suryati., dan I. I. Arief. 2016. Effectiveness of the Red Dragon Fruit (Hylocereus polyrhizus) Peel Extract as the Colorant, Antioxidant, and Antimicrobial on Beef Sausage.Jurnal Farmasi. Volume 40 (1): 47-54

Nurmahani, M.M., Osman., Abdul H., Mohamad G., dan Pak Dek. 2012. ShortCommunication Antibacterial Property of Hylocereus polyrhizus and Hylocereus undatusPeel Extracts.Jurnal Farmasi. Volume 1 (19): 71-84

Perry, A. L dan Lambert, P. A. 2006. Propionibacterium acnes. Brimingham: Aston University.

Syamsuni. 2006. Farmasetika Dasar dan Hitungan Farmasi. Edited by W. R. Syarief. Jakarta: EGC

Sunarmi, S. And Yulianto, S. 2017. Formulasi Masker Gel Antioksidan Mengandung Ekstrak Kulit Buah Naga Merah (Hylocereus Polyrhizus). Interest: Jurnal Ilmu Kesehatan, 6(1).

Wahdaningsih, S., E. K. Untari., dan Y. Fauziah. 2014. Antibakteri Fraksi n - Heksan Kulit Hylocereus polyrhizus Terhadap Staphylococcus epidermidis dan Propionibacterium acnes. Jurnal Farmasi. Volume 1(3): 183-190 